\title{
Exercise as Therapy: Health and Well-Being
}

\author{
Trevor Archer ${ }^{*}$
}

Department of Psychology, University of Gothenburg, Sweden

\begin{abstract}
Physical exercise, in several guises, improves health and delivers a multitude of benefits for the aging brain and body, not least by delaying the aging process, but also by, its "scaffolding effect", buttressing the physiological processes vulnerable to that level of credibility. The present account is based upon a systematic survey of published studies outlining the benefits of physical exercise an intervention to improve diverse health aspects, with the key-words "Physical exercise and Health" among all biomedical sources. Under conditions of neuropsychiatric and neurologic illhealth, child-adolescent maturation during healthy and illness developmental trajectories, neuroimmune and affective unbalance, and epigenetic pressures, exercise offers a large harvest of augmentations in health and well-being. Both animal models and human studies support the premise of manifest gains from regular exercise within several domains, besides cognitive function and mood, notably as the agency of a noninvasive, readily available therapeutic intervention.
\end{abstract}

Keywords: Exercise, health, well-being, cognition, mood, anti-inflammation, epigenetics, therapy.

Under neuropsychiatric and ill-health conditions, physical exercise has proven remarkably beneficial whether partaken at beginning, under the course of or during the twilight of the human life-cycle [1-8] and under a variety of disorder [9-11] and occupational [1214] conditions. For example, using computer games to assess attentional span [15], it was found that intense exercise improved the attention of children with ADHD thereby facilitating school performance at a level comparable to undiagnosed children. Remarkably, just four minutes of within-classroom high-intensity interval physical activity (off-task behavior) improved selective attention performance in nine- to eleven-year-old children [16-18]. Academic performance and health outcomes are threatened by, psychological complaints and overweight in children and adolescents [19], these outcomes express a remarkable degree of coexpression [20-22], as well as links between affective disorders and eating disorders [23, 24]. Regardless of year of birth, cardiorespiratory fitness and weight status were shown independent and combined to be related to academic achievement in seventh-grade students within different cohorts [25]; this evidence offers further support that aerobically fit and normal weight pupils are more likely to express higher levels of performance at school. Nevertheless, several factors affect exercise participation: Taking into account cultural factors in Eastern Mediterranean regions, it has been postulated that the propensity for exercise among female university students requires much further attention from the perspective of health and well-being [26]. Not least, the conditions under which physical education is acquired may be critical: e.g. Whipp et al. (2015) [27]

*Address correspondence to this author at the Department of Psychology, University of Gothenburg, Sweden; Tel: +46 31 7864694;

Fax: +46 31 7864628; E-mail: Trevor.archer@psy.gu.se demonstrated that non-reciprocal peer-teachers who had received formalized support through training and tactical games approach-based teaching resources expressed enhanced behavioral, pedagogical, and motor performance outcomes in physical education training. It has been observed that performance at call centers was directly related to "opportunities to develop", the character strength clusters of "Wisdom" and "Knowledge", "Temperance" and the "Frequency of exercise" [28].

In the present account, four types of well-being are considered: (i) Hedonic well-being which consists of deriving pleasure and happiness from different aspects of life ("feeling good"), (ii) Eudaimonia which consists of a mature and actively virtuous life-style ("doing good"), (iii) Wellness which consists of the absence of disease or infirmity ("good physical health"), and (iv) Prosperity which consists of consisting of success in endeavors and good fortune ("prosperity"). Contrastingly, illbeing may be defined as the absence of health, happiness and prosperity due to infirmity or physical disability, unhappy or dissatisfied, socially isolated or alienated, unsuccessful or unfulfilled. Health has been described variously to conform with a state of physical, mental and social well-being through which individuals apply their own abilities, cope with the normal stresses of life, live and work productively, fruitfully and constructively, with adequate community contribution [29, 30]. Health indicates the level of functional or metabolic efficiency of living organisms; in this regard the type and extent of physical exercise may be critical. For instance, the influence of physical activity upon Subjective well-being was examined through an analysis of individuals' participation intensity and duration of sports activities [31]. It was observed that for participation intensity show that the number of days during which individuals 
practiced at moderate intensity in the week prior to the interview induced a significant and positive effect on Subjective well-being, whereas the number of days with vigorous-intensity activity has a significant and negative impact.

\section{HEALTH-PROMOTION THROUGH EXERCISE}

The childhood-adolescence developmental phase places an overload of intrinsic stress and life-demand burdens upon individuals seeking maturity in the emotional, cognitive, motor and neurobiological domains [32, 33] and ought to be considered in conjunction with the "biological embedding" of childhood stress and trauma experiences [34]. However, physical exercise influences academic performance and well-being positively, and often invariably, in children and adolescents [4], a strong indication of its benefits for cognitive-affective expressions. These types of exercise interventions present advantages, not only regarding reduced stress, anxiety and depression, but also improved self-esteem and psychological well-being [8, 35-38]. Cardiorespiratory capacity (measured on the 20-meter shuttle-run test) and motor ability were linked independently with all academic variables in children and adolescents ( $N=2038$, aged 6 to 18 years), despite adjustment for fitness and fatness indicators [39]. On the other hand, muscular strength was not linked with academic performance, independent of the other two physical fitness components, agility and coordination. In the present context, the combined adverse effects of low cardiorespiratory capacity and motor ability on academic performance observed across the risk groups ought to be noted particularly. In a study of healthy men and women, it was observed that regular exercise protects against the negative emotional outcomes of stress, and suggest that exercise exerts beneficial effects in healthy individuals [40]. Finally, in a population of 165 primary school children (aged 10-12 years), the physical exercise habit-strength was associated positively with higher levels of short-term memory [41], which were in turn associated with higher levels of academic performance; the authors concluded that the exercise habit is positively associated with cognitive ability and mediates the negative effect of distress.

Introducing exercise regimes is beneficial to health and well-being, both under laboratory and clinical conditions and has been demonstrated using a variety of health biomarkers. For example, in aged male rats (20-months-old, known for their obesity under sedentary conditions), treadmill exercise attenuated age-related cognitive decline in the inhibitory avoidance test, reduced pro-inflammatory biomarkers, TFN- $\alpha$ levels, and elevated histone $\mathrm{H} 4$ acetylation levels, associated with enhanced transcriptional activity related to improved epigenetic outcome, in hippocampal tissue $[42,43]$. Additionally, in groups of children and young adults with repaired tetralogy of Fallot, a 3-month aerobic dynamic exercise training schedule induced levels of 'good' maintenance of regional ventricular performance [44]. Physical exercise influences cognitive, emotional, learning and neurophysiological domains, both directly and indirect, thereby rendering it essential that this noninvasive, non-pharmacological intervention ought to form a part of children's and adolescents' long-term health programs [3]; its utility has been examined in wide range of inflammatory conditions [45]. The epigenetics of health benefits arising from regular physical exercise is documented increasingly [46, 47]. Several antiinflammatory actions of physical activity are accessible: e.g., 6 weeks of voluntary running wheel activity, in male Wistar rats prior to colitis-induction using trinitrobenzene sulphonic acid challenge was assessed [48]. They measured colonic gene (TNF- $\alpha$, IL-1 $\beta$, CXCL1 and IL-10) and protein (TNF- $\alpha$ ) expressions of various inflammatory mediators and enzyme activities of heme oxygenase (HO), nitric oxide synthase (NOS), and myeloperoxidase (MPO) enzymes. It was observed that the activities of $\mathrm{HO}$, constitutive NOS (cNOS) isoform were increased. The exercise regime decreased significantly TNBS-induced inflammatory markers, including extent of lesions, severity of mucosal damage, and gene expression of IL-1 $\beta$, CXCL1, and MPO activity whereas IL-10 gene expression and cNOS activity were elevated; iNOS activity was reduced and the activity of $\mathrm{HO}$ enzyme increased in comparison with the sedentary TNBStreated group. Thus, the anti-inflammatory role of exercise through (i) down-regulation of proinflammatory mediator gene expression, (ii) induction of anti-inflammatory mediators, and (iii) modulation of $\mathrm{HO}$ and NOS enzyme activity. A further therapeutic role of exercise has been found in manifestation of cardiovascular integrity: matrix metalloproteinases were shown to exert major influence in cardiac remodeling through the facilitation of physiological adaptation to exercise [49]. Certainly, the context/environment features (see below) under which exercise is engaged upon may be influential. Emotional well-being was a consistent positive effect of outdoor exercise whereas general health factors were linked to 
both indoor and outdoor exercise/activity [50]; outdoor exercise was important too for improving sleep quality, an aspect that may be essential to alleviation of depressive symptoms. Similarly, the proximal exercise outcome condition (temporal) was predictive of intrinsic motivation [51].

\section{MOOD IMPROVEMENT THROUGH EXERCISE}

Exercise induces antidepressant effects as reflected by several expressions of depressiveness [52, 53], not least through implementing self-efficacy and other indicators of well-being. In contrast, lack/absence of exercise/activity through a sedentary existence has prompted the conclusion that every third Australian child/adolescent between the ages of 5 years and 19 years has been predicted to be classified as overweight or obese by the year 2025 , with childhood obesity being associated with multiple immediate physical and psychological, depression, low self-esteem and lower scores of health-related quality of life, health comorbidities as well as co-morbidities in adulthood [54]. In a foot-shock-model of depression in rats, treadmill running exercise alleviated the depressive symptoms, immobility and suppression of climbing behavior, and increased the biomarkers whose reduction is indicative of depression, i.e. reduced expressions of serotonin (5$\mathrm{HT}$ ), tryptophan hydroxylase (TPH), and HT-1A receptors, in the dorsal raphe in the stress-induced rats [55]. Archer et al. (2014) [3] outlined the beneficial effects of physical exercise regimes upon cognitive, executive function and working memory, emotional, reduced self-esteem and depressed mood, motivational, anhedonia and psychomotor retardation, and somatic/physical, sleep disturbances and chronic aches and pains, categories of depression. Concomitantly, the amelioration of several biomarkers linked with depressive states: hypothalamic-pituitaryadrenal axis (HPA) homeostasis, antineurodegenerative effects, monoamine metabolism regulation, and neuroimmune functioning, bolsters the notion of exercise as a "scaffolding" that buttresses available network circuits, anti-inflammatory defences, neuroreparative processes, e.g. mobilization of brainderived neurotrophic factor (BDNF) and epigenetic development. Certainly, in university students exercise provided quite a strong alleviation of depressive symptoms [56]. Despite the promise of exercise benefits for depressive disorders the paucity of systematic studies on the effects of exercise intensity, duration and frequency awaits further research [57]. The effects of a six-month exercise regime consisting of aerobics (walking and running) and strength and flexibility exercises upon measures of fitness (bioimpedance scale and a stadiometer) and depressiveness (Yesavage's Geriatric Depression Scale) was studied in a group of 26 elderly patients [58]. Significant improvements were obtained in depressive symptoms, and in all physical fitness tests excepting the flexibility tests whereas their waist circumference reduction underlined the positive effects of exercise intervention.

\section{EXERCISE AS AN EPIGENETIC INTERVENTION}

Physical exercise offers an epigenetic propensity that holds benefits with several health domains, particularly for children and adolescents [59]. Despite issues linked to population selection and quantification of exercise, the overall pattern emerging appears to be a product of the utilization of global methylation as an outcome measure, not depicting changes in DNA methylation at the gene-specific level. Thus, particular genes may be methylated differentially in response to exercise-activity; nevertheless, certain genes may be hypomethylated, and others hypermethylated, thereby causing little to no global alteration [60]. In order to study genomic mechanisms involved in exerciseinduced behavioral changes, Kim et al. (2015) [61] examined whether or not the effects of restrain stress treatment upon depression-induction and amygdaloid biomarkers together with exercise-induced reversal. Chronic restrain stress induced depressive behaviors, immobility and time spent in target zone that were ameliorated by the scheduled forceful exercise intervention. These behaviors were accompanied by a global reduction of G9a histone methyltransferase and $\mathrm{H} 3 \mathrm{~K} 9 \mathrm{me} 2$ at the oxytocin and argenine vasopressin promoters; exercise intervention increased the levels of G9a histone methyltransferase and $\mathrm{H} 3 \mathrm{~K} 9 \mathrm{me} 2$ at the oxytocin and arginine vasopressin promoters in the basolateral amygdala which was linked to suppression of oxytocin and arginine vasopressin expression. In a social defeat-stress (resident intruder) model of anxiety and depression in rats, Patki et al. (2014) [62] studied the influence of moderate treadmill exercise (over 2 weeks) upon anxiety-like behaviors and cognitive performance. Both social defeat induced anxiety-like behavior, e.g. time in light region, ambulation, distance travelled and fecal boli counts, and memory impairments (errors in the radial arm maze), and corticosterone levels were alleviated by the exercise regime which normalized social defeat induced elevations of oxidative stress markers (prate in carbonylation, and protein levels of GLO-1/ $\beta$-actin, GSR-1/ $\beta$-actin, Mn-SOD/ $\beta$-actin, and Cu-Zn SOD/ $\beta$ - 
actin). The presence of epigenetic mechanism was implicated histone acetylation of $\mathrm{H} 3$ and methyl-CpGbinding modulation in the hippocampus; specifically exercise reversed the stress-induced reduction of BDNF/ $\beta$-actin, p-CREB/t-CREB, CAMKIV/ $\beta$-actin and elevations of $p$-ERK[1/2)/t-ERK(1/2)] and IL-6/ $\beta$-actin. Finally, Lindholm et al. (2015) [63] observed the contribution of DNA methylation and associated transcriptomic changes emerging from exercisetraining regimes. These authors obtained consistent and associated modifications, DNA methylation in enhancers, gene bodies and intergenic regions and to a lesser extent in $\mathrm{CpG}$ islands or promoters, in methylation and expression, concordant with observed health-enhancing phenotypic adaptations.

\section{CONCLUSIONS}

The manifest health-beneficial expressions of physical exercise over individuals' life-cycles, whether normal or in ill-health, may be encapsulated within several domains of welfare: (i) exercise and academic performance, (ii) exercise and the developmental trajectory, (iii) exercise for the alleviation of affective disorders, and (iv) the epigenetic manifestations of physical exercise. Surprisingly, the effects of exercise may be determined relatively quickly: just eight weeks of pre-season training on body composition, physical fitness, anaerobic capacity, and isokinetic strength in collegiate taekwondo athletes in endurance gave improvements on all these parameters, as assessed by relative peak power and anaerobic capacity and angular velocity $[64,65]$.

\section{REFERENCES}

[1] Archer T. Physical exercise alleviates debilities of normal aging and Alzheimer's disease. Acta Neurol Scand 2011; 123: $221-238$.

http://dx.doi.org/10.1111/j.1600-0404.2010.01412.x

[2] Archer $T$. Influence of physical exercise on traumatic brain injury deficits: scaffolding effect. Neurotox Res 2013; 21: 418-434.

http://dx.doi.org/10.1007/s12640-011-9297-0

[3] Archer T. Health benefits of physical exercise for children and adolescents. J Novel Physiother 2014; 4: 2. http://dx.doi.org/10.4172/2165-7025.1000203

[4] Archer T, Garcia D. Physical exercise influences academic performance and well-being in children and adolescents. Int J School Cogn Psychol 2014. DOI: 10.4172/12343425.1000e.102.

[5] Archer T, Garcia D. Exercise and dietary restriction for promotion of neurohealth benefits. Health 2015; 7: xx-xx, DOI: $10.4236 /^{\star \star \star *} .2015$. $^{\star \star \star \star *}$.

[6] Archer T, Josefsson T, Lindwall M. Effects of physical exercise on depressive symptoms and biomarkers in depression. CNS \& Neurological Disorders - Drug Targets 2014; 13: 000-000.
Archer T, Kostrzewa RM. Physical exercise alleviates ADHD symptoms: regional deficits and developmental trajectory. Neurotox Res 2012. http://dx.doi.org/10.1007/s12640-011-9260-0

[8] Garcia D, Archer T. Positive affect and age as predictors of exercise compliance. Peer J 2014; 2: e694. http://dx.doi.org/10.7717/peerj.694

[9] Janzon E, Abidi T, Bahtsevani C. Can physical activity be used as a tool to reduce depression in patients after a cardiac event? What is the evidence? A systematic literature study. Scand J Psychol 2015; 56(2): 175-81. http://dx.doi.org/10.1111/sjop.12190

[10] Mack DE, Meldrum LS, Wilson PM, Sabiston CM. Physical activity and psychological health in breast cancer survivors: an application of basic psychological needs theory. Appl Psychol Health Well-Being 2013; 5: 369-388.

http://dx.doi.org/10.1111/aphw.12016

[11] Maruf FA, Akinpelu AO, Salako BL. Self-reported quality of life before and after aerobic exercise training in individuals with hypertension: a randomized-controlled trial. Appl Psychol Health Well-Being 2013; 5: 209-224.

http://dx.doi.org/10.1111/aphw.12005

[12] Nägel IJ, Sonnentag S. () Exercise and sleep predict personal resources in employees' daily lives. Appl Psychol Health Well-Being 2013; 5: 348-368. http://dx.doi.org/10.1111/aphw.12014

[13] Rebar AL, Stanton R, Geard D, Short C, Duncan MJ, Vandelanotte C. A Meta-Meta-Analysis of the effect of physical activity on depression and anxiety in non-clinical adult populations. Health Psychol Rev 2015; 5: 1-78. http://dx.doi.org/10.1080/17437199.2015.1022901

[14] Shoham DA, Dugas LR, Bovet P, Forrester TE, Lambert EV, Plange-Rhule J, Schoeller DA, Brage S, Ekelund U, DurazoArvizu RA, Cooper RS, Luke A. Association of car ownership and physical activity across the spectrum of human development: Modeling the Epidemiologic Transition Study (METS). BMC Public Health 2015; 15: 173.

http://dx.doi.org/10.1186/s12889-015-1435-9

[15] Silva AP, Prado SO, Scardovelli TA, Boschi SR, Campos LC Frère AF. Measurement of the effect of physical exercise on the concentration of individuals with ADHD. PLoS One 2015; 10(3): e0122119.

http://dx.doi.org/10.1371/journal.pone.0122119

[16] Ma JK, Le Mare L, Gurd BJ. Classroom-based high-intensity interval activity improves off-task behaviour in primary school students. Appl Physiol Nutr Metab 2014; 39(12): 1332-7. http://dx.doi.org/10.1139/apnm-2014-0125

[17] Ma JK, Le Mare L, Gurd BJ. Four minutes of in-class highintensity interval activity improves selective attention in 9- to 11-year olds. Appl Physiol Nutr Metab 2015; 40(3): 238-44. http://dx.doi.org/10.1139/apnm-2014-0309

[18] Etnier J, Labban JD, Piepmeier A, Davis ME, Henning DA. Effects of an acute bout of exercise on memory in 6th grade children. Pediatr Exerc Sci 2014; 26(3): 250-8.

http://dx.doi.org/10.1123/pes.2013-0141

[19] Pulgaron ER. Childhood obesity: a review of increased risk for physical and psychological comorbidities. Clin Ther 2013; 35: A18-A32.

http://dx.doi.org/10.1016/j.clinthera.2012.12.014

[20] Moola FJ, Faulkner GE, Schneiderman JE. "No time to play": perceptions toward physical activity in youth with cystic fibrosis. Adapt Phys Activ Q 2012; 29(1): 44-62.

[21] Schneiderman JE, Wilkes DL, Atenafu EG, Nguyen T, Wells GD, Alarie N, Tullis $E$, Lands LC, Coates AL, Corey $M$, Ratjen F. Longitudinal relationship between physical activity and lung health in patients with cystic fibrosis. Eur Respir $\mathrm{J}$ 2014; 43(3): 817-23.

http://dx.doi.org/10.1183/09031936.00055513 
[22] Wells GD, Wilkes DL, Schneiderman JE, Rayner T, Elmi M, Selvadurai H, Dell SD, Noseworthy MD, Ratjen F, Tein I, Coates AL. Skeletal muscle metabolism in cystic fibrosis and primary ciliary dyskinesia. Pediatr Res 2014; 69(1): 40-5. http://dx.doi.org/10.1203/PDR.0b013e3181fff35f

[23] Ferreiro F, Wikström L, Seone G, Senra C. Reciprocal associations between depressive symptoms and disordered eating among adolescent girls and boys: a multiwave, prospective study. J Abnorm Child Psychol 2013; 42(5): 80312.

http://dx.doi.org/10.1007/s10802-013-9833-x

[24] Korczak DJ, Lipman E, Morrison K, Duku E, Szatmari P. Child and adolescent psychopathy predicts increased adult body mass index: results from a prospective community study. J Dev Behav Pediatr 2014; 35: 108-117. http://dx.doi.org/10.1097/DBP.0000000000000015

[25] Sardinha LB, Marques A, Martins S, Palmeira A, Minderico C. Fitness, fatness, and academic performance in seventhgrade elementary school students. BMC Pediatr 2014; 14: 176.

http://dx.doi.org/10.1186/1471-2431-14-176

[26] Ansari WE, Labeeb S, Moseley L, Kotb S, El-Houfy A. Physical and psychological well-being of university students: survey of eleven faculties in Egypt. Int J Prev Med 2013; 4: 293-310.

[27] Whipp PR, Jackson B, Dimmock JA, Soh J. The effects of formalized and trained non-reciprocal peer teaching on psychosocial, behavioral, pedagogical, and motor learning outcomes in physical education. Front Psychol 2015; 6: 149. http://dx.doi.org/10.3389/fpsyg.2015.00149

[28] Moradi S, Nima AA, Rapp Ricciardi M, Archer T, Garcia D. Exercise, character strengths, well-being, and learning climate in the prediction of performance over a 6-month period at a call center. Front Psychol 2014; 5: 1-11. http://dx.doi.org/10.3389/fpsyg.2014.00497

[29] Callahan D. The WHO definition of health. Center Studies 1973; 1: 77-87. http://dx.doi.org/10.2307/3527467

[30] Vögele C. On living a long, healthy, and happy life, full of love, and with no regrets, until your last breath. Verhaltenstherapie 2013; 23: 287-289. http://dx.doi.org/10.1159/000357548

[31] Wicker $P$, Frick $B$. The relationship between intensity and duration of physical activity and subjective well-being. Eur $\mathrm{J}$ Public Health 2015; pii: ckv131.

http://dx.doi.org/10.1093/eurpub/ckv131

[32] Armstrong B, Westen SC, Janicke DM. The role of overweight perception and depressive symptoms in child and adolescent unhealthy weight control behaviors: a mediation model. J Pediatr Psychol 2014; 39: 340-348. http://dx.doi.org/10.1093/jpepsy/jst091

[33] Forrest CB, Bevans KB, Riley AW, Crespo R, Louis TA. Health and school outcomes during children's transition into adolescence. J Adolesc Health 2013; 52: 186-194. http://dx.doi.org/10.1016/j.jadohealth.2012.06.019

[34] Dich N, Hansen ÅM, Avlund K, Lund R, Mortensen EL, Bruunsgaard $\mathrm{H}$, Rod $\mathrm{NH}$. Early life adversity potentiates the effects of later life stress on cumulative physiological dysregulation. Anxiety Stress Coping 2015; 28(4): 372-90. http://dx.doi.org/10.1080/10615806.2014.969720

[35] Dunton GF, Huh J, Levanthal AM, Riggs N, Hedeker D, Spruijt-Metz D, Pentz MA. Momentary assessment of affect, physical feeling states, and physical activity in children. Health Psychol 2014; 33: 255-263. http://dx.doi.org/10.1037/a0032640

[36] Hoying J, Melnyk BM, Arcoleo K. Effects of the COPE Cognitive Behavioral Skills Building TEEN Program on the Healthy Lifestyle Behaviors and Mental Health of
Appalachian Early Adolescents. J Pediatr Health Care 2015; pii: S0891-5245(15)00077-2.

http://dx.doi.org/10.1016/j.pedhc.2015.02.005

[37] Gaz DV, Smith AM. Psychosocial benefits and implications of exercise. Am Acad Phys Med Rehab 2012; 4: 812-817. http://dx.doi.org/10.1016/j.pmri.2012.09.587

[38] Melnyk BM, Jacobson D, Kelly S, Belyea M, Shaibi G, Smal $\mathrm{L}$, O'Haver J, Marsiglia FF. Promoting healthy lifestyles in high school adolescents: a randomized control trial. Am J Prev Med 2013; 45: 407-415.

http://dx.doi.org/10.1016/j.amepre.2013.05.013

[39] Esteban-Cornejo I, Tejero-González CM, Martinez-Gomez D, del-Campo J, González-Galo A, Padilla-Moledo C, Sallis JF, Veiga OL, UP \& DOWN Study Group. Independent and combined influence of the components of physical fitness on academic performance in youth. J Pediatr 2014; 165(2): 306312.e2. http://dx.doi.org/10.1016/j.jpeds.2014.04.044

[40] Childs E, de Wit $\mathrm{H}$. Regular exercise is associated with emotional resilience to acute stress in healthy adults. Front Physiol 2014; 5: 161.

http://dx.doi.org/10.3389/fphys.2014.00161

[41] Zainol NA, Hashim HA. Does exercise habit strength moderate the relationship between emotional distress and short-term memory in Malaysian primary school children? Psychol Health Med 2015; 20(4): 495-502. http://dx.doi.org/10.1080/13548506.2014.955034

[42] Lovatel GA, Elsner VR, Bertoldi K, Vanzella C, Moysés Fdos S, Vizuete A, Spindler C, Cechinel LR, Netto CA, Muotri AR, Siqueira IR. Treadmill exercise induces age-related changes in aversive memory, neuroinflammatory and epigenetic processes in the rat hippocampus. Neurobiol Learn Mem 2013; 101: 94-102. http://dx.doi.org/10.1016/j.nlm.2013.01.007

[43] Lovatel GA, Bertoldi K, Elsnerb VR, Piazza FV, Basso CG Moysés Fdos S, Worm PV, Netto CA, Marcuzzo S, Siqueira IR. Long-term effects of pre and post-ischemic exercise following global cerebral ischemia on astrocyte and microglia functions in hippocampus from Wistar rats. Brain Res 2014; 1587: 119-26.

http://dx.doi.org/10.1016/j.brainres.2014.08.068

[44] Duppen N, Geerdink LM, Kuipers IM, Bossers SS, Koopman LP, van Dijk AP, Roos-Hesselink JW, De Korte CL, Helbing WA, Kapusta L. Regional ventricular performance and exercise training in children and young adults after repair of tetralogy of fallot: randomized controlled pilot study. Circ Cardiovasc Imaging 2015; 8(4): pii: e002006. http://dx.doi.org/10.1161/circimaging.114.002006

[45] Thomas JL. Helpful or harmful? Potential effects of exercise on select inflammatory conditions. Phys Sports Med 2013; 41: $93-100$ http://dx.doi.org/10.3810/psm.2013.11.2040

[46] Archer T. Epigenetic changes induced by exercise. J Reward Defic Syndr 2015; 1: xx-yy.

[47] Ling C, Rönn T. () Epigenetic adaptation to regular exercise in humans. Drug Discov Today 2014; pii: S13596446(14)00083-X. DOI: 10.1016/j.drudis.2014.03.006.

[48] Szalai Z, Szász A, Nagy I, Puskás LG, Kupai K, Király A, Berkó AM, Pósa A, Strifler G, Baráth Z, Nagy LI, Szabó R, Pávó I, Murlasits Z, Gyöngyösi M, Varga C. Antiinflammatory effect of recreational exercise in TNBS-induced colitis in rats: role of NOS/HO/MPO system. Oxid Med Cell Longev 2014; 2014: 925981. http://dx.doi.org/10.1155/2014/925981

[49] Pósa A, Szabó R, Kupai K, Baráth Z, Szalai Z, Csonka A Veszelka M, Gyöngyösi M, Radák Z, Ménesi R, Pávó I, Berkó AM, Varga C. Cardioprotective effects of voluntary exercise in a rat model: role of matrix metalloproteinase-2. Oxid Med Cell Longev 2015; 2015: 876805.

http://dx.doi.org/10.1155/2015/876805 
[50] Pasanen TP, Tyrväinen L, Korpela KM. The relationship between perceived health and physical activity indoors, outdoors in built environments, and outdoors in nature. App Psychol Heal Well-Being 2014; 6: 324-346. http://dx.doi.org/10.1111/aphw.12031

[51] Evans MB, Cooke LM, Murray RA, Wilson AE. The sooner, the better: exercise outcome proximity and intrinsic motivation. App Psychol Heal Well-Being 2014; 6: 347-361. http://dx.doi.org/10.1111/aphw.12032

[52] Feldstain A, Lebel S, Chasen MR. An interdisciplinary palliative rehabilitation intervention bolstering general selfefficacy to attenuate symptoms of depression in patients living with advanced cancer. Support Care Cancer 2015. http://dx.doi.org/10.1007/s00520-015-2751-4

[53] Vancampfort D, Madou T, Moens H, De Backer T, Vanhalst P, Helon C, Naert P, Rosenbaum S, Stubbs B, Probst M. Could autonomous motivation hold the key to successfully implementing lifestyle changes in affective disorders? A multicentre cross sectional study. Psychiatry Res 2015; pii: S0165-1781(15)00212-7.

http://dx.doi.org/10.1016/j.psychres.2015.04.021

[54] Sanders RH, Han A, Baker JS, Cobley S. Childhood obesity and its physical and psychological co-morbidities: a systematic review of Australian children and adolescents. Eur J Pediatr 2015.

http://dx.doi.org/10.1007/s00431-015-2551-3

[55] Kim TW, Lim BV, Baek D, Ryu DS, Seo JH. Stress-Induced Depression Is Alleviated by Aerobic Exercise Through UpRegulation of 5-Hydroxytryptamine 1A Receptors in Rats. Int Neurourol J 2015; 19(1): 27-33. http://dx.doi.org/10.5213/inj.2015.19.1.27

[56] Yan S, Jin YZ, Oh YS, Choi YJ. Effect of exercise on depression in university students: a meta-analysis of randomized controlled trials. J Sports Med Phys Fitness 2015.

[57] Thomson D, Turner A, Lauder S, Gigler ME, Berk L, Singh AB, Pasco JA, Berk M, Sylvia L. A brief review of exercise, bipolar disorder, and mechanistic pathways. Front Psychol 2015; 6: 147.

http://dx.doi.org/10.3389/fpsyg.2015.00147

[58] Branco JC, Jansen K, Sobrinho JT, Carrapatoso S, Spessato B, Carvalho J, Mota J, da Silva RA. Physical benefits and reduction of depressive symptoms among the elderly: results from the Portuguese "National Walking Program". Cien Saude Colet 2015; 20(3): 789-95. http://dx.doi.org/10.1590/1413-81232015203.09882014

[59] House SH. Transgenerational healing: Educating children in genesis of healthy children, with focus on nutrition, emotion, and epigenetic effects on brain development. Nutr Health 2014; 22(1): 9-45. http://dx.doi.org/10.1177/0260106013506666

[60] Horsburgh S, Robson-Ansley P, Adams R, Smith. Exercise and inflammation-related epigenetic modifications: focus on DNA methylation. Exerc Immunol Rev 2015; 21: 26-41.

[61] Kim TK, Lee JE, Kim JE, Park JY, Choi J, Kim H, Lee EH, Han PL. G9a-mediated regulation of OXT and AVP expression in the basolateral amygdala mediates stressinduced lasting behavioral depression and its reversal by exercise. Mol Neurobiol 2015. DOI: 10.1007/s12035-0159160-z.

[62] Patki G, Solanki N, Atrooz F, Ansari A, Allam F, Jannise B, Maturi J, Salim A. Novel mechanistic insights into treadmill exercise based rescue of social defeat-induced anxiety-like behavior and memory impairment in rats. Physiol Behav 2014; 130: 135-144.

http://dx.doi.org/10.1016/j.physbeh.2014.04.011

[63] Lindholm ME, Marabita F, Gomez-Cabrero D, Rundqvist $H$, Ekström TJ, Tegnér J, Sundberg CJ. An integrative analysis reveals coordinated reprogramming of the epigenome and the transcriptome in human skeletal muscle after training. Epigenetics 2015; 9(12): 1557-69. http://dx.doi.org/10.4161/15592294.2014.982445

[64] Seo MW, Jung HC, Song JK, Kim HB. Effect of 8 weeks of pre-season training on body composition, physical fitness, anaerobic capacity, and isokinetic muscle strength in male and female collegiate taekwondo athletes. J Exerc Rehabil 2015; 11(2): 101-7. http://dx.doi.org/10.12965/jer.150196

[65] Garcia D, Archer T, Moradi S, Andersson-Arntén AC. Exercise frequency, high activation positive affect, and psychological well-being: beyond age, gender, and occupation. Psychology 2012.

http://dx.doi.org/10.4236/psych.2012.34047 